Canadian Journal of Higher Education Revue canadienne d'enseignement supérieur

Volume 46, No. 2, 2016, pages 1 - 18

\title{
Performing Internationalization of Higher Education in Canadian National Policy
}

Melody Viczko and Clara I. Tascón

Western University

\begin{abstract}
Internationalization processes are at the fore of university strategic plans on a global scale. However, the work of internationalization is being performed through the connections between many actors at different policy levels. Our purpose here is to ask, what is happening with internationalization of higher education at the Canadian national policy level? To do so, we suggest that we must look at policies at the national level not as individual entities but rather as these policies exist in relation to each other. We examine three recent policy statements from different organizations at the national level in Canada: a federal governmental agency, a pan-Canadian provincial organization and a national educational association. Our approach involved mapping the actors, knowledges and spaces that are discursively produced through these texts and engaging a relational approach to policy analysis that questions what comes to be assembled as these policies co-exist in the national landscape.
\end{abstract}

\section{Résumé}

À l'échelle mondiale, les processus d'internationalisation se trouvent à l'avant-centre des plans stratégiques universitaires. Toutefois, le travail d'internationalisation s'effectue par des relations entre de nombreux acteurs, à différents niveaux de politique générale. Nous étudions le statut d'internationalisation de l'enseignement supérieur à l'échelle des politiques nationales du Canada. Nous émettons la possibilité d'étudier les politiques 
à l'échelle nationale, plutôt qu'à une échelle individuelle. Nous analysons également comment ces politiques coexistent entre elles. Nous décortiquons trois récents énoncés de politique émis par différentes organisations de niveau national au Canada : une agence fédérale gouvernementale, une organisation provinciale pancanadienne et une association éducative nationale. Notre approche consistait à cartographier les acteurs, à analyser les connaissances et espaces produits de manière discursive par ces énoncés de politique, et à entreprendre une approche relationnelle d'analyse de politiques qui remet les énoncés en cause, tandis que ces politiques coexistent sur la scène nationale.

\section{Introduction}

Internationalization processes are at the fore of university strategic plans on a global scale. However, many governmental bodies and non-governmental associations have released policy statements aimed at internationalizing higher education institutions (Robertson et al, 2012; Viczko, 2013; Wright \& Ørberg, 2008). Consequently, the internationalization of higher education institutions increasingly takes part through the relations between universities and actors located outside the formalized organizational boundaries of higher education (Robertson et al, 2012; Shultz \& Viczko, 2012; Viczko, 2013), which means the work of internationalization of higher education is being performed through the connections between many actors at different policy levels.

In the Canadian context, the network of actors engaged in internationalizing universities is expanding (Shubert, Jones, \& Trilokekar, 2009; Viczko, 2013) and the interdependencies between national-level organizations and universities are of interest to scholars and practitioners alike (Jones \& Olesksiyenko, 2010). Although higher education remains the jurisdiction of provincial governments, several federal government departments and national non-governmental organizations have recently produced policies related to internationalization. For example, the Department of Foreign Affairs, Trade and Development (DFATD) launched its strategy for international education in early 2014. Policies such as these enrol, that is, connect, a multiplicity of actors from education, international trade, immigration, and corporate communities. Given the increasing interactions between these national-level organizations and universities, the performance of internationalization at Canadian higher education institutions emerges in relation with national policy discourses. Consequently, there is a need to understand these policies and their impact on higher education policies and practices. Specifically in this article, we ask, what is happening with internationalization of higher education at the Canadian national policy level?

The purpose of this article is to identify and interrogate within the Canadian context emerging policies related to the internationalizing higher education in organizations at the national level. We explore what is happening at the national level among different actors with interests in higher education. Our approach involved mapping out the actors, knowledges, and spaces (Brock, McGee \& Gaventa, 2004) that are discursively produced through three policy documents from the national scene in Canada. However, mapping efforts are political (Robertson et al., 2012), and so we also engage in a policy analysis that questions the powers of association (Latour, 1986) in what come to be assembled as different actors are enrolled, knowledges are promoted, and spaces for engagement are created through these policy texts. 


\section{Internationalization of Higher Education and National Interests}

The emergent participation of different national actors in the policy making of the internationalization of higher education is a highly contested topic, not only in the policy realm but also in the academic arena in Canada. Higher education is the domain of provincial and territorial jurisdictions in this country, as the result of constitutional arrangements. However, the international dimension of higher education and its increased attention as a global trend during the last thirty years has brought the association of other national actors, knowledges, and spaces to the fore. Moreover, the internationalization of higher education has become connected to the diplomatic relations of Canada with other countries across the world that are seeking to be truly engaged in the global knowledge economy (Trilokekar, 2009). The engagement of different actors changes not only the interests involved but also affects the power relations between actors (Latour, 1986; Latour, 2005). In order to understand the ways in which the enrolment of national actors changes the terrain of the educational networks involved in governing higher education, it is important to consider the influences of these transformations in the policy space and why the internationalization of higher education is situated as a diplomatic and strategic move in Canada's economic prosperity.

Internationalization of higher education is steeped in the development of the global knowledge economy and is influenced by neoliberal reforms to governance (Olssen \& Peters, 2005) that constitute "the form through which domestic and global economic relations are structured" (p. 313). Neoliberalism is the state rationality that ensures the privileging of free trade and the freedom of knowledge as a form of global capital are commodified and marketed internationally. Here, we do not conflate neoliberalism and internationalization. Rather, we agree with the position of Olssen and Peters (2005) who argue that neoliberal reforms to state governance have deeply influenced the governance of higher education, and consequently the ways in which universities themselves are constructed as actors has also changed. Key to this change is the shift in higher education from a traditional notion of knowledge as a public good to capital that can be marketed and traded. This shift changes the image of the higher education institutions and, in so doing, changes the expectations of the education they provide (Olssen \& Peters, 2009; Torres \& Van Heertum, 2009). Moreover, an expanding relationship among industry, government, and academia claims to prepare leaders and skilled, entrepreneurial individuals who are able to work in a globalized world (Olssen, 2009). In this context, the notion of the knowledge economy becomes powerful for framing social change as driven by economic processes that work to "construct institutional arrangements, power relations and a particular ordering of social positions, which mark out social inclusions and exclusions" (Seddon, 2009, p. 260). Such orderings are the effects of the assemblage of the networks (Law, 2009) involved in higher education governance. The influences of neoliberalism are not superficial in their effect on the governance of higher education: by changing the network of actors, knowledges, and spaces involved, higher education itself changes.

Bloom (2005) outlines two mechanisms through which higher education becomes essential to nation state prosperity on an international scale. First, through access to higher education, individuals are equipped with necessary skills and knowledge to embrace the changes and demands of fast-paced global movement of people and resources. Conse- 
quently, higher education provides knowledge and access to knowledge that allows nation states to arrive at informed decisions when negotiating solutions to their problems. To this extent, higher education as capital becomes instrumental in nurturing students' training that will help them facilitate access to markets, attract foreign capital, and establish links with local and foreign companies. Second, the global movement of students and labour brings benefits to countries by providing an exchange that focuses on developing knowledge and solving problems. Knowledge is then not only understood as traditional academic knowledge but as knowledge that "is produced in-use, linked to the functional imperatives of the world of work" (Olsen \& Peters, 2005, p. 330). Hence, knowledge is capital.

In addition, the internationalization of higher education in national contexts plays an important role in strengthening scientific collaborative networks on an international scale. Senior science managers of the Canadian government point out that being recognized in international scientific communities brings Canada the opportunity to be more competitive with other countries (Isabelle \& Heslop, 2011). Knowledge then creates reputation and a way to foster wealth and influence through international scientific collaborations. To engage in these endeavours, each nation state must find the right partners for sharing the costs of research and resources through diplomatic international relationships.

\section{Theoretical Concepts}

In this article, policy is conceptualized as "a social and political space articulated through relations of power and systems of governance" (Shore \& Wright, 1997, p. 14). Policy is studied in a networked approach that recognizes that policy ideas interact with other policy fields (Rizvi \& Lingard, 2010). Shore \& Wright argue policy has agency: it creates links between agents, institutions, technologies, and discourses (Shore \& Wright, 2011).

The conceptual and analytical framework in this research draws upon the work of Brock, McGee and Gaventa (2004). This framework is helpful in mapping out the complexities of policies by considering the actors, knowledge, and spaces involved in policy processes. As Brock, McGee, and Gaventa (2004) argued the making and doing of policy happens through dynamic interactions between actors, and knowledge, and policy spaces. The nexus between these interactions may be ambiguous, as they are imbued with historical, cultural, and political significance, but produce power to "shape all aspects of the context, the policy spaces themselves and the way actors and knowledge interrelate in them" (McGee, 2004, p. 23). This analytical framework goes beyond a one-dimensional view often achieved through the mapping of actors alone. More important, we find this framework a meaningful way to interrogate the dynamics of power as the actors become associated through policy.

Robertson et al. (2012) recognized the complexity in any account of power in order to understand the transformations taking place between levels of policy in higher education. As they stated, "No process is ever innocent in terms of politics. Mapping, for instance, engages us in ways of looking at the spatiality of power" (p. 53). Latour (1986) suggested the exercise of power is an effect, rather than a cause. He explains that power is a consequence of collective action, highlighting a performative definition. In this respect, power is made and is not something that actors inherently are granted based on the authority of their positions. As Latour (1986) described, it is through the action of defining or redefining "what 'holds' everyone together" (p. 273) that actors accumulate power from those who 
are doing the action. This is Latour's notion of power through translation. Koyama (2011) describes the concept of translation as "a process in which different actors come together, influence and change one another, and create linkages that eventually form a network of action and material" (p. 24). Researchers interested in the idea of power through translation are involved in "redefin[ing] who is acting, why it is necessary to act together, what are the boundaries of the collective, how responsibility should be allocated" (Koyama, 2011, p. 276). It is for this reason that Latour redefined the study of how power operates as the study of associations, how actors and organizations hold together the relations they are composed in and how these relations generate power for particular actors.

\section{Methodology}

This qualitative study focuses on the nature of internationalization that is performed through textual documents. The methodology is informed by a sociomaterial approach (Latour, 2005; Law, 2009) to research that considers policies as actants (Latour, 2005) with agency to perform realities (Fenwick \& Edwards, 2010). The word "perform" is intentional here, to show that internationalization is something that is put into action. Our methodology involved a relational analysis of policy, drawing on Shore and Wright (2011) who assert, "it is precisely the way that policy creates links between agents, institutions, technologies and discourses and brings all of these diverse elements into alignment that makes it analytically productive" (p. 11).

Data collection for this project involved two phases. First, we conducted an environmental scan of the policy landscape to begin to understand the scope of policies at play. We looked for policies, statements, and position papers currently being referenced in higher education institutions, national organizations, and government websites. Then, using content analysis (Sarantakos 2005), we identified the actors, knowledges, and spaces in each text, drawing on the framework developed by Brock, McGee, and Gaventa (2004).

Subsequently, a more discursive analysis followed as we selected three policies that we could interrogate relationally. In this level of analysis, we looked not only at what the policies say but also the order and structure that texts discursively produce (Law, 2009). Analysis involved examining the ways in which these policies produce discursive stability by defining the conditions of possibility in which internationalization is practised, "making some ways of ordering webs of relations easier and others difficult or impossible" (Law, 2009, p. 149). Our purposes here are to explore the three policies in order to map out what is occurring at the national level in Canada, in order to understand the ordering practices occurring in the field. Our position is that in order to understand the national level, we need to understand the policies not only as individual texts but also how they sit side-by-side discursively.

We present three collected policy statements from three different actors in the Canadian national arena: the federal Department of Foreign Affairs, Trade and Development $\left(\right.$ DFATD $^{1}$ ); the Council of Ministers of Education, Canada (CMEC) in collaboration with the Council of the Federation representing the premiers and ministers of the Canadian provincial governments; and a national association, the Canadian Bureau of International Education (CBIE). The selection of documents from these organizations was to provide representation from different arenas of policymaking that target national-level responses to internationalization (and other higher education interests): the federal government, 
provincial governments working collectively through a pan-Canadian organization, and a national non-governmental actor that comprised of members from several higher education institutions throughout Canada.

\section{Three Policy Statements}

Our presentation of these policy statements relates to the content analysis involved in describing the actors, knowledges, and spaces in each of three selected policy texts in Canada in the chronological order they were released.

\section{Bringing Education in Canada to the World, Bringing the World to Canada}

The Council of the Ministers of Education, Canada (CMEC) in partnership with the provincial ministers of immigration proposed a plan for international education marketing to the premiers at the Council of the Federation in June 2011. The development of this plan-Bringing Education in Canada to the World, Bringing the World to Canada: An International Education Marketing Action Plan for Provinces and Territories, June 2011-involved consultations with the provincial ministries of education, universities and colleges in Canada, and other stakeholders interested in international education. The focus of the plan is the recruitment and retention of international students in Canadian higher education institutions and provinces.

The policy in the plan is built around two schemes to produce internationalization: marketing the brand of Canadian education and facilitating the mobility of students. The plan is aimed at provincial actors and determines the ways in which internationalization ought to unfold from provincial priorities, with support from federal agencies. In this way, Council of the Federation asserts the authoritative position of the provinces over education as a jurisdiction, drawing on the historical (though controversial) decentralization of education in Canada (Jones, 2009). This marketing plan focuses on individual priorities at the provincial and territorial level, with multiple actors and multiple strategies: "[i]t is important that provinces and territories lead in promoting Canada's education systems on the international scene" (CMEC, 2011, p. 10). The assertion of the individual interests of provincial and territorial actors is a reflection of the diversity of higher education in Canada with regard to institutional and regulatory structures and funding schemes (Jones, 2009). As a pan-Canadian organization, the Council of the Federation is a central actor in the development of this plan, which brings together provincial interests and provides a forum for provincial premiers and government ministers to meet collectively on issues of both provincial and federal jurisdiction.

This provincial marketing plan emphasizes the importance of branding the education product from Canada. The plan identifies different markets as targets to enhance provincial and territorial competitiveness using the Canadian brand, Imagine Education $\mathrm{au}$ /in Canada. In this way, these actors emphasize their own leadership regarding the unique provincial and territorial initiatives and internationalization of higher education programs with the support of the federal agencies, such as Department of Foreign Affairs, Trade and Development (DFAT) and Citizenship and Immigration Canada (CIC). The Imagine Education in/au Canada brand is managed by CMEC, an organization of the provincial ministers of education, so its assertion of the significance of this brand is an 
effort to again position education within provincial powers. This positioning is important because the federal agencies are not excluded but are positioned in a supportive role, maintaining the primacy of the provincial and territorial right to lead the governance of internationalization. Furthermore, the brand, emphasizes establishing offices in key markets to deliver a new brand strategy that can be disseminated through the web at trade events and conferences. Internationalization in this provincial marketing plan is intrinsically linked to market rationality that aims to deliver market-based intelligence that focuses on providing service for a customer need (Olssen \& Peters, 2005).

The area of policy knowledge elaborated in the plan points to developing knowledge around student mobility as the central purpose for internationalizing higher education, and it defines specific outcomes in terms of increasing recruitment and retention of international students to supply labour force demands. These outcomes include increasing the number of international students studying in Canada and retaining those who remain in Canada as permanent residents after graduation. The plan details specific objectives to increase transparency of the process of acquiring a study permit and calls for collaborations with CIC and visa-processing actors in order to improve strategize and efficiently administer immigration regulations. A further object of the plan is to increase Canadian student mobility abroad and suggests a need to develop core competencies so that the students may "become ambassadors" through alumni networks. Key to the release of the plan is the promotion of soft and managerial skills, whereby students are become highly qualified professionals, able to contribute to the Canadian labour market both in at home and abroad.

The spaces created in the production of this plan began through invited consultation of the provincial and territorial policy network. This consultation involved federal agencies, educational institutions from all sectors (with emphasis on those working with international students), education marketing agencies, and other stakeholders. The provincial and territorial actors call for support and collaboration from the federal government to facilitate "speak[ing] with one voice on education to foreign governments or international organizations" (CMEC, 2011, p. 10). This claim reveals the ambiguous position of the provincial actors regarding the spaces of consultation. The purpose of the consultation, as suggested in the plan, was to work on a comprehensive marketing campaign, yet tensions between the individual and collective voices of the provinces leave uncertainty in simultaneous freedom for provinces to determine their own educational strategies and ambiguity in how actors are to come together around the plan.

The tensions between national, and provincial and territorial jurisdiction are steeped in the historical context of the Canadian constitution. It assigns the responsibility for education to the provinces and the they have long asserted their exclusive right for educational governance (Jones, 2009). However, with continued seeping of national interests into the development of the knowledge economy, resistance by the provinces to federal control continues to build in the articulation of this policy plan.

\section{Pre-Budget Consultation Submission to the House of Commons Standing Commission on Finance}

The Canadian Bureau for International Education (CBIE) is a national organization for higher educational institutions and associations working on educational issues in Canada. As a member-based organization, CBIE also links with both Canadian and inter- 
national private sectors and international organizations to develop partnerships, scholarship programs, and connections with educational actors across the globe. CBIE engages in partnerships "to expand the international connections of Canada's education sector and to introduce Canadian education and training expertise to new clients" (CBIE, 2014). The organization also works closely with the federal government to lobby for international education support and initiatives.

Prior to the federal 2013 budget, CBIE released their submission-House of Commons Standing Commission on Finance [L2]: Pre-Budget Consultations 2013 Submission from the Canadian Bureau for International Education, August 2, 2013-to the consultation meetings of the Standing Committee of Finance, held through the House of Commons, the democratically elected arm of the Parliament of Canada. As a recognized international education stakeholder, CBIE lobbies on behalf of its educational members to the federal government and submitted a list of recommendations to be considered in the formulation of the budget. Although this submission from CBIE is not a policy statement in terms of governing specific legislative edicts, this document is nonetheless influential on the national policy landscape. We turned to the CBIE document because the organization embodies the involvement of higher education institutions at the national level. While the document is not legislative in nature, it aims to influence decision-making, in Ball's (2000) words, "[to] create circumstances in which the range of options in deciding what to do are narrowed or changed" (p. 1834). Here, we see policy as a process (Shore \& Wright, 2011), not as a final articulation of a singular text. For us, the CBIE lobbying efforts represent a moment along the policy process.

In relation to CBIE's membership, the submission statement mentions a number of actors that are included as partners and beneficiaries. Among a series of recommendations in the submission, there are three that relate specifically to the formation of partnerships. First, the recommendation to focus on investment in study abroad for Canadian students associates the participation of the private sector in supporting Canadian students in studying abroad. These efforts are linked to enhancing further employability. Also, with the support of the private sector, business, manufacturers, exporters, and foreign governments, Canada will ensure the education of leaders for enhancing relations in target countries such as Brazil and China.

Second, the recommendation to centre the investment in collaborative international partnerships between educational institutions hones in on strategic markets such as Brazil, China, and India, as international actors in the Canadian international education plan. Thus, students, researchers, and educational leaders will be supported according to strategically identified fields and establish partnerships with these target markets. Through these partnerships, Canada attempts to attract institutional partners and talented students from abroad.

Third, the investment in the promotion of education in Canada emphasizes the benefits international students provide to Canada. Among them are the interactions between international and Canadian students, the contribution of international student fees to Canada's revenue generation, the added jobs for products and services that may be filled by educated international students who remain as Canadian immigrants, and tourism revenue provided by international students' parents. The actors involved in internationalization are broad and bring a multitude of interests to Canada's expanding education. 
The knowledges promoted through the recommendations are mainly oriented to prepare students to fully participate with trade interests in the global knowledge economy. To accomplish this goal, CBIE highlights the knowledges and skills acquired abroad that promote Canadian economic growth: international knowledge and managerial skills and leadership. In relation to the investment in collaborative international partnerships, this statement supports education and basic and applied research as well as curriculum design in strategic fields such as agriculture and food, environment, health, and technology where partnerships would reap significant economic benefit.

CBIE's recommendations are generated through the closed space of its membership. However, it is important to note that CBIE is a member-based organization, composed of educational institutions, international education brokers, and associations related to specialized niches, such as language education, within the international education market. The recommendations are submitted on behalf of this broad membership, and CBIE lobbies the federal government based on the interests of its members. Their submission of the recommendations to the House of Commons Standing Commission on Finance is one example.

\section{Canada's International Education Strategy}

In consultation with the federal ministers of international trade and finance, the Canadian federal government established an advisory panel to develop a comprehensive international education strategy-Canada's International Education Strategy: Harnessing Our Knowledge Advantage to Drive Innovation and Prosperity, 2014. The advisory panel represented senior administration from both higher education institutions and private industry. These panel members were chosen by the ministries as political appointments, each of which had background and experience in both "education and marketing in Canada and abroad" (DFATD, 2014, p. 5). In addition to the advisory panel and the ministers of international trade and finance, the strategy links multiple actors within the policy network at the federal level: DFATD; CIC; Employment and Social Development Canada, the International Development Research Centre, Canadian postsecondary institutions and research centres, educational associations, CMEC, and other stakeholders within the industry sector. The list also involves actors who are interconnected abroad, such as institutions, research centres, and Canadian embassies and consulates. The purpose of the strategy is to respond to market demands and is a tailored approach to priority markets (Brazil, China, India, Mexico, North Africa, Middle East, and Vietnam). However, the strategy is designed to address competing markets (France, UK, Germany, Japan, Korea, and USA) and includes flexibility for strategic manoeuvring with other emerging markets. It is also explicit in its focus on the Imagine Education au/in Canada brand as a tool to market Canada as a world-class destination for higher education, and as a reliable education and trade partner. In this sense, the strategy facilitates an expansion of Canada's presence in emerging and competing markets by embracing an educational environment to foster economic growth.

Canada's International Education Strategy places the Government of Canada in a strategic leadership role within a partnership with the provinces and territories, via CMEC as a pan-Canadian organization. This approach attempts to position Canada internationally by "leveraging people-to-people ties" (DFATD, 2014, p. 11) through students, researchers, alumni networks, and Canada's diplomatic networks. The positioning of the federal government as a central figure in internationalization is central to distinguishing the federal level as the powerful actor. 
Other key actors are brought into the policy through four areas: foreign students studying in Canada, Canadians studying abroad, educational and research institutes collaboration inside and outside Canada, Canadian education programmatic models and deliverance of the Canadian online education around the world. Specifically, the strategy identifies goals that fit into five categories: (1) double the number of international students and researchers (up to 450,000 students) as well as retain more of these students after graduation, (2) enhance two-way student and research mobility, institute international research partnerships, and leverage alumni networks, (3) assign resources to priority markets and their embassies and develop a marketing and branding plan according to these market needs, (4) foster innovative programs and online education and leverage Canada's bilingual and multicultural identity, and (5) support coordinated activities among governments with CMEC and other stakeholders.

The policy knowledge in the strategy is aligned directly with innovation, related to job creation, economic growth, and the "diplomacy of knowledge" (DFATD, 2014, p. 5). The concept of diplomacy of knowledge is significant in this document; it is invoked to strengthen Canada's innovation edge and competitiveness according to global economic trends, thereby enhancing the export of Canada's know-how. Some areas of knowledge are highlighted: the mining, agriculture, and forest sectors; innovation in nanotechnology, quantum computing, human genome research, and digital media. The notion of diplomacy pervades Canada's International Education Strategy; his Excellency the Right Honourable David Johnston, Governor General of Canada is quoted: "diplomacy of knowledge [entails] the process of uncovering, sharing and refining all kinds of knowledge across disciplinary boundaries and international borders" (DFATD, 2014, p.15). The document illuminates a broad spectrum of knowledges where not only disciplinary knowledges count but also the intersection of cross-disciplinary action across local, national, and global levels counts. It highlights how interdisciplinary knowledge strengthens interactions among faculty, students, researchers, and industry partners when crossing international borders.

Input into the strategy was provided by an online survey and round-table discussions across Canada, and by a two-day session of collaborative discussions among a variety of partners and stakeholders. The advisory panel consulted a series of topics through surveys (250 submissions) with educational institutions and other educational associations to query topics as diverse as the recruitment of students in undergraduate and postgraduate programs, Canadian partnerships with foreign educational institutions, Canadian curricula sold and leased, offshore campuses of Canadian institutions, and international research collaborations. The round-table discussions gathered participants' views of how the strategy could help attain established goals. The panel consulted almost 250 organizations including all provincial and territorial governments and CMEC. The two-day session of collaborative discussions included 57 partners and stakeholders who consensually defined the priorities for the panel's recommendations. This strategy aims to create international policy spaces characterized by partnerships and collaborations with other countries.

\section{The Power of National Actors in Internationalization Policies}

Developing an understanding of the national policy landscape of the internationalization of higher education involved the political act of mapping the policies involved in internationalization (Robertson et al. 2012). To carrying out this mapping we used 
a relational approach: we did not seek to consider the content alone in each policy, but rather we examined how these policies discursively exist side-by-side as they bring different associations of actors, knowledges, and spaces to the fore. That is, we are interested in the relations between the policies as they co-exist in the policy landscape. This relational analysis questions the powers of association (Latour, 1986), meaning we will examine what comes to be assembled as different actors are enrolled, knowledges are promoted, and spaces for engagement are created through these policy texts. We will discuss what is happening in the internationalization of higher education at the national level in Canada by focusing on the power dynamics that emerge in the assembling of these policies, specifically, the question of what comes to be powerful relationally in the association of actors, knowledges, and spaces in these three policy statements.

The scale of Canadian strategies for the internationalization of higher education is neither uniform nor unified. Although neoliberalism underpins the three policy statements, characterized by the marketization of higher education through internationalization, there are idiosyncrasies between the three policies that we aim to highlight. While it is clear that there is an overlapping of actors, spaces, and knowledge among these policies, how the actors are enrolled, spaces are defined, and knowledges are produced do not result in similar assemblages. Consequently, we argue the ways these actors, spaces, and knowledges are assembled in each policy produce a disconnected policy landscape at the national level.

In the CMEC policy statement, the provinces and territories advocate for a pan-Canadian marketing approach, using the national brand Imagine Education au/in Canada but they emphasize a multivoiced strategy. The international education marketing action plan supports the Canadian brand for a global identity as a destination for educational opportunities, but at the same time, it emphasizes the individual provincial and territorial right to lead the governance of internationalization. The provinces and territories multivoice position emphasizes that "[u]nlike countries with centralized strategies, Canada's federal nature should allow it to benefit from multiple strategies that deploy different approaches and target different markets [. . .] while still leveraging the advantages of the shared brand" (CMEC, 2011, p. 10). By mapping what is happening at the provincial and territorial level, the actors support their own distinct strategies, and spaces are open for consultation that anticipates the federal support. With the expected federal support, provinces and territories can focus their marketing plan for recruitment and retention of students as a strategic move in the interests of the higher education mandate.

To this extent, the plan engages a tension inherent in the federal system of governance in Canada. The play between the collective power of the Council of the Federation and the individual autonomy that sets provincial and territorial priorities is a tension the plan brings to the fore. Consequently, the decision to pursue a multivoiced strategy ensures that the actions of the collective group of provinces do not diminish the power of the provinces in their individual efforts to set their own priorities strategically. Thus, the provincial and territorial approach retains international education control in collaboration with federal support. Indeed, the power of the provinces and territories is asserted in this plan.

However, this provincial-based plan did not resonate with the policy strategy at the federal level. The DFATD document recognized the work of CMEC and Council of the Federation in developing the market plan as indicating the possibilities for individual 
and collective partnerships with the federal government. Yet, the focus on marketing to students through mobility programs does not take precedence in the federal strategy. Furthermore, the CMEC plan criticizes the federal government's lack of interest in building federal- provincial and territorial collaboration. This tension is historical (Jones, 2009) and was played out in the Canadian media during the November 2012 meetings between the provincial and territorial leaders and the federal government when the provincial leaders indicated their disappointment in the absence of the prime minister as the national leader (CBC, 2012; Chronicle Herald, 2012). Darrell Dexter, premier of Nova Scotia, summarized the attending premiers' frustration: "It's difficult for us to know how we can best blend our own planning in with the funding of the federal government if we don't know what their plans are" (CBC, 2012, para 3). The tensions between collective and bilateral relations are not easily reconciled through policy, and the struggle to define who holds control over internationalization is likely to continue.

DFATD's international education strategy includes the participation of the different actors from the provinces and territories in Canada as collaborators to achieve the federal strategic goals. Its policy document states, "[w]ith the support of all the players in the research in the education fields-provinces and territories, educational institutions, nongovernmental organizations, the private sector-we can make Canada a world leader in international education and ensure our future prosperity" (DFATD, 2014, p. 4). However, in the document the nation state's interests are positioned centrally, and decision-making power is held to be a federal issue in defining the internationalization of higher education as a diplomatic initiative to contribute to Canada's economic prosperity. This initiative promotes the national brand, Imagine Education au/in Canada, for marketing on a national level to targeted geographical areas. With the goal of positioning Canada's international education opportunities at the forefront of the international education market, this strategy promotes two-way student mobility-recruitment and retention of foreign students studying in Canada and the creation of opportunities for Canadian students studying abroad.

But the DFATD strategy also focuses on support for international research collaborations inside and outside Canada, and enhancement of Canadian curriculum and online programs abroad. Diplomacy of knowledge and leveraging the human capital through people-to-people ties developed through the work in embassies and alumni networks are also promoted through this approach. The association of actors' in this strategy becomes an extensive network of interconnections nationally and abroad, thus maintaining a centralized governance of internationalization. This interrelation allows sharing knowledge across disciplinary and international boundaries to boost political, economic, social, and developmental relationships.

Diplomacy of knowledge is the means of job creation and economic growth that is asserted as necessary for Canada to be competitive in its participation in the knowledge economy. Higher education institutions are brought into the diplomacy relationship when they are included as partners with the federal government. While the provincial and territorial authority over the higher education institutions is not denied, it is also not actively acknowledged as a central aspect of the diplomatic program of DFATD. Rather we see a manifestation of the federal government's attempts to redefine the relationships with educational actors, which is a significant change in the relationship between national interests and the internationalization of higher education institutions. 
The move to diplomacy of knowledge, we argue, is a move to position internationalization as the work of foreign affairs and trade, bringing control for the internationalization of higher education into the realm of the nation state, not the provincial educational authorities. Latour (1986) reminds us that redefining who is acting is an important powerful move, in this case, for contrtol of the role of higher education institutions in building national prosperity through research, student mobility, and educational partnerships. Furthermore, as Seddon (2009) suggests, institutional arrangements between actors produce "a particular ordering of social positions" (p. 260) that are key to the ways in which social inclusions and exclusions are mapped. The privileging of a relationship between national interests and higher education institutions is key to asserting the power of the nation state in influencing how internationalization ought to play out in Canada.

CBIE's policy document emphasizes the association between higher education institutions and industry as a central outcome of the internationalizing processes in higher education. As a national member-based organization, CBIE promotes partnerships between Canadian and international actors in the private sector through scholarships and research projects. The assembling of actors identified in this policy document entwines extensive relationships with different national and international stakeholders who dispense a differing dynamics in the academic arena. There is a marked emphasis on the preparation of skills, training capacity, and expertise. With this aim, CBIE recommends the government support Canadian students who wish to study abroad in order to gain leadership and managerial skills that will enhance their employment opportunities in Canada and abroad.

There is also tactical interest in participating in partnerships that link research and industry in Canada with target markets, particularly Brazil and China. To further this goal, bringing international students to study in Canada and supporting students abroad through international research collaborations contribute to the country's economic growth. Hence, CBIE's recommendations focus on internationalization of higher education as a driving force for the local and global knowledge economy. CBIE's prebudget submission is a direct appeal to the federal government, and as such it advances the role of industry into the national policy landscape for internationalization while also legitimizing the role of the national government in shaping higher education strategies. The document also positions skill building to complement the needs of industry, promoting the relationship between higher education institutions and internationalization efforts of the federal government. While provincial and territorial jurisdictions play an inherent role in governing skill and labour development across the country, CBIE's appeal to the federal government further legitimizes DFATD in its central role in internationalization efforts in higher education.

Positioning DFATD as central in international education governance creates it as a powerful organization. Here, Latour's (1986) idea that something like an organization can be powerful not through its own work alone, but also through the activities of others is relevant. The DFATD plan reinforces the interests and appeals of CBIE and, consequently, connects to the actors for whom that CBIE represents. In this way, the work of DFTAD's policy is to create itself as a central player in determining directions of higher education internationalization and to generate itself as a powerful actor as other actors work to support its position. 


\section{Conclusion}

The three national policy documents reviewed in this paper focused on the internationalization of higher education in the Canadian context. We drew on a relational analysis with two phases. First, using content analysis, we identified the actors, knowledges, and spaces in each text. Second, we engaged a more discursive analysis that looked at not only what the policies say but also on the order and structure that texts discursively produce (Law, 2009). Our purpose was to explore the three policies in order to map out what is happening at the national level in Canada to understand the ordering practices occurring in the field. The relational analysis we engaged elucidates what is happening at the national level by examining the policies not only as individual texts but also how they discursively exist at the same time in the policy landscape.

Although these three documents support the Canadian branding Imagine Education in/au Canada as a crucial national venture on an international scale, we identified important tensions that are pronounced in the specific approach to each policy text within the group of actors, knowledge, and spaces. We note the tension between the provincial and territorial domains of higher education as it has been traditionally honoured and federal endeavours to own and drive internationalization as a diplomatic venture. Therefore, the provincial and territorial approach to internationalization is a multivoice strategy that is minimized by the federal approach. It is by looking at the texts relationally that we are able to see this tension.

Furthermore, the relational analysis helps us to see the prevalence of an assumed neoliberal discourse in the different policy texts. At the federal level through the DFATD policy, supported through the position of CBIE, this neoliberal discourse is enforced by aligning Canadian economic growth with the diplomacy of knowledge in order to pursue this country's prosperity. The representation of higher educational institutions at the national level linked the institutions to industry stakeholders, reinforcing an instrumentalist view of education. Olssen and Peters (2005) argue that the pervasive neoliberal rationality of the state assumes a role for universities in building the knowledge economy, and through the DFATD policy, we see this role supporting the national trade agenda. However, the neoliberal discourse of the CMEC plan was not focused on privileging the nation state but rather on establishing the boundaries for provincial and territorial authorities to determine their own role in the national knowledge economy through their relationship with the universities. These three policy texts present, in one way or the other, Canada's attempt to enrol universities in the knowledge economy by enhancing internationalization of higher education as a force for prosperity.

This is an analysis of documents, and as such, it has limitations about what we can know about the policy context. We propose that more research needs to be undertaken to better understand what is happening at the national level in the internationalization of higher education. We recognize that universities are increasingly pressured to support and align with a globalized neoliberal agenda through internationalization. However, we do not assume that such hegemony precludes opportunities to act otherwise. It is beyond the scope of this paper to examine the intentions of university institutions themselves to consider their own positions in embracing or resisting the influence of neoliberalism, though we do not mean to suggest that higher education institutions themselves are neu- 
tral in their engagement with the national policy landscape. In any case, we make four recommendations for continued research in this area.

First, we need empirical studies that examine the enactment of these policies in higher education practices and governance. By doing so, it will be possible to better know in what ways these policies have become meaningful for those working in higher education. Specifically, we think the ways in which higher education institutions enact their roles as actors and spectators is an important distinction that will show the power of these policies in bringing about changes to governance practices.

Second, we need studies that consider the relationship that develops between these policies as they enacted. By this, we assert that each of these policies does not exist as an independent entity. There are multiple ways that these policies can be woven together and taken up in relation to the priorities of higher education institutions themselves.

Third, as Jones (2009) points out, the landscape of higher education institutions is multiple and changing in the Canadian context. For example, we see many changes in the transformation of colleges to degree-granting universities, and the ways in which these institutions participate in the national policy landscape is worth considering.

Fourth, in our analysis, we have considered each actor in homogenous ways, which is a limitation when conducting policy analysis of policy texts. However, case studies that focus on describing the ways that actors come to be defined through the enactments of policies can build more a thorough understanding of the changes of these policies in the higher education context.

\section{Note}

1 This federal department was restructured and retitled Global Affairs Canada with the 2015 election of the Liberal Government. We are using the name of the department at the time of writing: Department of Foreign Affairs, Trade and Development.

\section{References}

Ball, S. J. (2000). What is policy? Texts, trajectories and toolboxes. In S. J. Ball (Ed.), The sociology of education: Major themes (pp. 1830-1840). London, UK: Routledge.

Bloom, D. E. (2005). Raising the pressure: Globalization and the need for higher education reform. In M.L. Skolnik, P.L. McCarney, \& G. A. Jones (Eds.), Creating knowledge, strengthening nations: the changing role of higher education (pp. 21-41). Toronto, ON: University of Toronto Press.

Brock, K., McGee, R., \& Gaventa, J. (Eds) (2004). Unpacking policy: Knowledge, actors and spaces in poverty reduction in Uganda and Nigeria. Brighton, UK: Fountain.

CBC(Canadian Broadcasting Company).(2013). Harper snub threatens to overshadow premiers meeting. Retrieved from http://www.cbc.ca/news/canada/nova-scotia/harpersnub-threatens-to-overshadow-premiers-meeting-1.1239645

CBIE (Canadian Bureau for International Education). (August 2, 2013). House of Commons Standing Commission on Finance: Pre-Budget Consultations 2013 Submission from the Canadian Bureau for International Education. Retrieved from: http://www.cbiebcei.ca/wp-content/uploads/2013/03/CBIE_Pre-BudgetConsultations2013_EN.pdf 
CBIE(Canadian Bureau for International Education).(2014). CBIEto expand education partnerships with Government of Canada support. Retrieved from http://www.cbie.ca/ news/cbie-to-expand-education-partnerships-with-government-of-canada-support/

Chronicle Herald, (2012). Harper snubs premiers. Retrieved from http:// thechronicleherald.ca/novascotia/122928-harper-snubs-premiers

CMEC (Council of Ministers of Education, Canada). (June 2011). Bringing education in Canada to the world, bringing the world to Canada: An international education marketing action plan for provinces and territories. Retrieved from: http://www.cmec. ca/Publications/Lists/Publications/Attachments/264/COF_Bringing_Ed_to_Canada_ Eng_final.pdf

DFATD (Department of Foreign Affairs, Trade and Development Canada). (2014). Canada's International Education Strategy: Harnessing our knowledge advantage to drive innovation and prosperity, 2014. Retrieved from: http://international.gc.ca/ global-markets-marches-mondiaux/assets/pdfs/overview-apercu-eng.pdf

Fenwick, T., \& Edwards, R. (2010). Actor-network theory in education. London: Routledge.

Isabelle, D., \& Heslop, L. (2011). Managing for success in international scientific collaborations: Views from Canadian government senior science managers. Science and Public Policy, 38(5), 349-364. doi: 10.3152/030234211X12960315267534

Jones, G. (2009). Sectors, institutional types and the challenges of shifting categories: A Canadian commentary. Higher Education Quarterly, 63(4), 371-383. doi: 10.1111/j.14682273.2009.00439.x

Jones, G., \& Oleksiyenko, A. (2010). The internationalization of Canadian university research: A global higher education matrix analysis of multi-level governance. Higher Education, 61(1):41-57. doi: 10.1007/s10734-010-9324-8

Koyama, J. (2011). Principals, power, and policy: Enacting "supplemental education services.”. Anthropology and Education Quarterly, 42(1), 20-36.

Latour, B. (1986). The powers of association. In J. Law (Ed.), Power, action and belief: A new sociology of knowledge? (pp. 264-280). London, UK: Routledge.

Latour, B. (2005). Reassembling the social: An introduction to Actor-NetworkTheory. London, UK: Oxford University Press.

Law, J. (2009). Actor network theory and material semiotics. In B. S. Turner (Ed.), The new Blackwell companion to social theory (3rd ed.) (pp. 141-158). Chichester, UK: Blackwell.

McGee, R. (2004). Unpacking policy: Actors, knowledge and spaces. In K. Brock, R. McGee, \& J. Gaventa (Eds.), Knowledge, actors and spaces in poverty reduction in Uganda and Nigeria (pp. 1-26). Brighton, UK: Fountain.

Olssen, M. (2009). Neoliberalism, education, and the rise of the global common good. In M. Simons, M. Olssen, \& M. Peters (Eds.) Re-reading education policies: A handbook for studying the policy agenda of the 21st century (pp.433-457). Rotterdam, The Netherlands: Sense. 
Olssen, M., \& Peters, M. (2005) Neoliberalism, higher education and the knowledge economy: From the free market to knowledge capitalism. Journal of Education Policy, 2O(3), 313-345. doi: 10.1080/02680930500108718

Rizvi, F., \& Lingard, B. (2010). Globalizing education policy. London, UK: Routledge.

Robertson, S. L., Dale, R., Moutsios, S., Nielsen, G., Shore, C., \& Wright, S. (2012). Globalisation and regionalism in higher education: Toward a new conceptual framework. In S. Wright (Ed.), Working papers on university reform, Working paper 20, EPOKE, Department of Education, Aarhus University.

Sarantakos, S. (2005). Social research. New York, NY: Palgrave Macmillan.

Seddon, T. (2009). Knowledge economy: Policy discourse and cultural resource. In M. Simons, M. Olssen, \& M. Peters (Eds.) Re-reading education policies: A handbook for studying the policy agenda of the 21st century (pp. 257-276). Rotterdam, The Netherlands: Sense.

Shore, C. \& Wright, S. (1997). Anthropology of policy: Critical perspectives on governance and power. London, UK: Routledge.

Shore, C., \& Wright, S. (2011). Conceptualising policy: Technologies of governance and the politics of visibility. In C. Shore, S. Wright, \& D. Pero(Eds.), Policyworlds: Anthropology and the analysis of contemporary power (pp. 1-26). New York, NY: Berghahn.

Shubert, A., Jones, G. A., \& Trilokekar, R. D. (2009). Introduction. In R. D. Trilokekar, G. A. Jones \& A. Shubert (Eds.), Canada's universities go global (pp. 7-15). Toronto, ON: James Lorimer.

Shultz, L., \&Viczko, M. (2012). Canadian responses to Bologna: Questions of legitimacy, authority and autonomy. Journal of the World Universities Forum, 5(1), 1-10.

Torres, C. A., \& Van Heertum, R. (2009). Globalization and neoliberalism. The challenges and opportunities of radical pedagogy. In M. Simons, M. Olssen \& M. A. Peters (Eds.), Re-reading education policies. A handbook for studying the policy agenda of the $21^{\text {st }}$ century (pp.143-162 ). Boston, MA: Sense.

Trilokekar, R. D. (2009). The Department of Foreign Affairs and International Trade (DFAIT), Canada: Providing leadership in the internationalization of Canadian higher education. In R. D. Trilokekar, G. A. Jones \& A. Shubert (Eds.), Canada's universities go global (pp. 98 - 118). Toronto, ON: James Lorimer.

Viczko, M. (2013). Internationalisation of Canadian higher education: Troubling the notion of autonomy through an examination of policy actors, knowledge and spaces. Learning and Teaching, 6(1), 26-46.

Wright, S., \& Ørberg, J. W. (2008). Autonomy and control: Danish university reform in the context of modern governance. Learning and Teaching, 1(1), 27-57. doi: 10:3167/ latiss2008.010104 


\section{Contact Information}

Melody Viczko

Critical Policy, Equity and Leadership Studies

Western University

mviczko@uwo.ca

Melody Viczko is an assistant professor Critical Policy, Equity And Leadership Studies in the Faculty of Education at Western University. Her research reflects broad interests in the areas of educational policy analysis and multiscalar governance. She engages qualitative approaches to research with a fascination for studying how actors assemble around policies and how policies are enacted through these assemblages. Her current research relates to the interactions between global, national, and local policy spaces in the internationalization of higher education.

Clara I. Tascón is a PhD candidate in Critical Policy, Equity and Leadership Studies at Western University. Her doctoral research focuses on internationalization of higher education. She examines how knowledge is produced in international research collaboration across borders through research networks in Canada and Colombia. She studies interconnections of global and local flows of knowledge, policies, and practices with different actors in distinct research networks. She draws on post-foundational approaches in comparative and international education and network analysis to map these interconnections with an interest in understanding the "interpretive zone" where knowledge production emerges. 